\title{
Water use innovations \& controlling recommendations for waterlogging on street \& open land
}

\author{
Prasanta Biswas $^{1 *}$, Sourojit Das ${ }^{2}$, Arindam Prasad Sinha ${ }^{3}$, Biltu Mondal ${ }^{4}$, Jayanta Kumar Karmakar ${ }^{5}$ Nabamita \\ Sen $^{6}$
}

\begin{abstract}
${ }^{1}$ Assistant Professor, Department Of Civil Engineering, Global Institute Of Management And Technology (G.I.M.T) West Bengal, India
${ }^{2}$ Assistant Professor, Department Of Civil Engineering, Global Institute Of Management And Technology (G.I.M.T) West Bengal, India ${ }^{3}$ H.O.D\& Assistant Professor, Department Of Civil Engineering, Global Institute Of Management And Technology (G.I.M.T) West Bengal, India

${ }^{4}$ Student, B.Tech 4th Year 7th Sem (MAKAUT University Roll No: 25901318133), Department Of Civil Engineering, Global Institute Of Management And Technology (G.I.M.T) West Bengal, India

${ }^{5}$ Student, B.Tech 4th Year 7th Sem (MAKAUT University Roll No: 25901318132), Department Of Civil Engineering, Global Institute Of Management And Technology (G.I.M.T) West Bengal, India

${ }^{6}$ Student, B.Tech 4th Year 7th Sem (MAKAUT University Roll No: 25901319088), Department Of Civil Engineering, Global Institute Of
\end{abstract} Management And Technology (G.I.M.T) West Bengal, India

DOI: 10.29322/IJSRP.11.12.2021.p12026

http://dx.doi.org/10.29322/IJSRP.11.12.2021.p12026

\begin{abstract}
Street waterlogging has become a common issue for Indian roads. More of it, there is the occurrence of standing water in open lands (fields) during monsoon season. Total water so formed on water-logging on streets, open-lands, etc. are the Point of issue of this research study. Various Innovative measures have been discussed in the study to how to use the locked in water by waterlogging. From the study, suitable measures could be reached at with proper estimation in background so determined to make the water use purpose practical. Lot of research scopes are in the study, both physical \& theoretical. It is ultimately to the mankind to be lived with less pollution problems as offered by waterlogging.
\end{abstract}

Index Terms- Monsoon rainfall, Street waterlogging, Water use innovation, Innovative treatment plant, Innovation strategy.

\section{INTRODUCTION}

$\mathrm{R}$ ight landscape distribution is an essential part of an infrastructure, in the waterlogging phenomenon. A city/township may not well behave to its various seasonal responses to natural calamity \& like provided its infrastructural design \& system are not correct to the sense of flow balancing. In any area, it is a foresighting experience of non-distribution of landscape with its various associated elements/components. Gridded estimation technique ${ }^{(1)}$ in that regard may be found to be a pathway to measure the population. There are three things to consider in any catchment area to avoid unnecessary waterlogging \& various other disruptions to daily city life activities \& these are to be:

- Population

- Population forecasting

- Distribution of population
Socio-demography status is a pertinent component of the third of the three. Also, if a landscape is required to be prepared of to 'desired' quality of level \& etc. it is to be not of anything definitely prior to detail 'prudent' planning.

It is found that most of the metro cities in India are presently facing with a problem of urban area deficits \& its proper landscape design problems. Rate of urbanization is becoming hugely increasing over so intensely that entire city would have faced the deficit overnight, seemingly. It may be the problem so, as the cities are expanding their territorial boundaries to greater distances, giving privileges to rural areas just with an idea that developmental index has come at their doorstep \& is expanding. Should it be a mark of development if a city expands its territory? However the scenario is highly practical \& growth of population is quite amazingly competitive among the cities (Table 1).

\section{Table 1: Growth of population of metropolitan cities in India}

\begin{tabular}{|l|l|l|}
\hline \multirow{2}{*}{$\begin{array}{l}\text { Metropolitan } \\
\text { Cities }\end{array}$} & Ranks \\
\cline { 2 - 3 } & Census Year 2001 & Census Year 2011 \\
\hline Mumbai & 1 & 1 \\
\hline Delhi & 3 & 2 \\
\hline Kolkata & 2 & 3 \\
\hline Chennai & 4 & 4 \\
\hline Bangalore & 6 & 5 \\
\hline Hyderabad & 5 & 6 \\
\hline
\end{tabular}

(Source: Census of India and Provisional Population census 2011) 


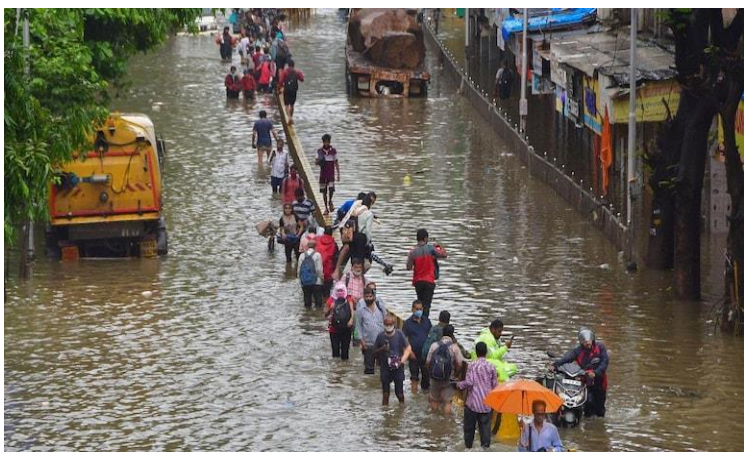

Figure 1.1: Commuters with anxiety to pass on a waterlogged street in Mumbai's Dadar (Photo: 26 July 2005) (Ref.2)

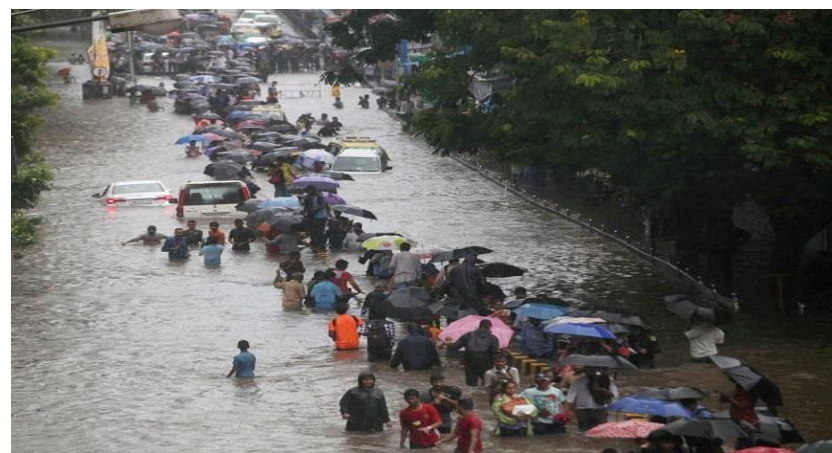

Figure 1.2: Waterlogging like flooded never before in Mumbai (Photo: 21 July 2021) (Ref.2)
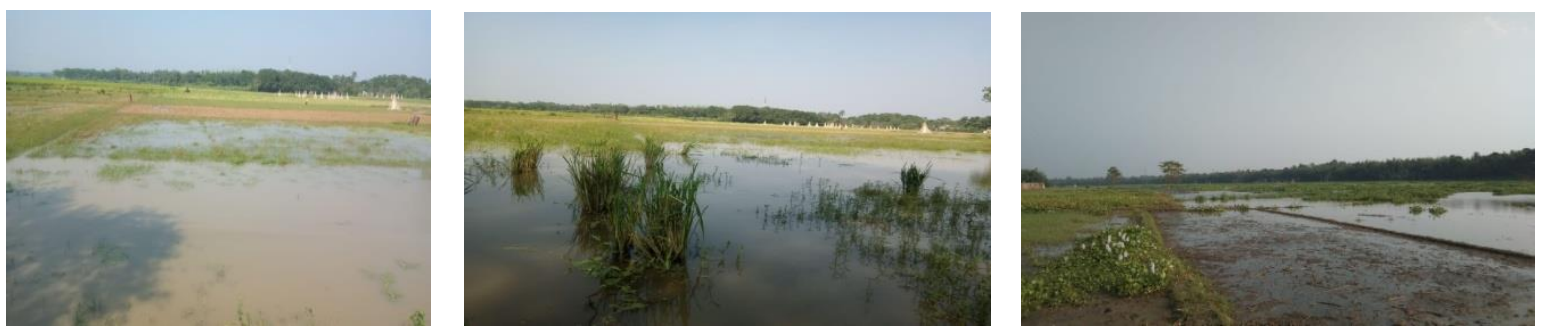

Figure 1.3: Waterlogging by heavy rainfall, cyclone, etc. in recent period (2020-2021) in West Bengal

Figure 1: Some instances of waterlogging in India

As per 2011 Census, population density of India is found to be equal to 382 persons per square kilometer \& growth of city Delhi is $25 \%$ for rural \& $75 \%$ for urban area ${ }^{(3)}$. Also, $31 \%$ of the country (India) population lived in urban areas according to the official statistics ${ }^{(4)}$. The practical data is not a rumour indeed than the scope (fearful!) \& reckoning pre-consideration underlying in it \& gives us the insight of how a city expands due to population explosion. Ultimately, economy of the city comes to a state of re-vision \& complex for that.
Also, about sizing potential of each family in India, as per 2011 Census, average size of a household in Delhi was found to be $5.02^{(4)}$. It indicates that in one house, there are more than five persons \& more than half of households had more than 5 members during the year 2011.

This preliminary insight so given is required to have a concept of knowing the perspectives of a city towards its water-logging scenario during monsoon season (Figure 1). This research paper is about finding \& giving an elaboration of what \& how the water-logging problem is \& could be solved respectively.
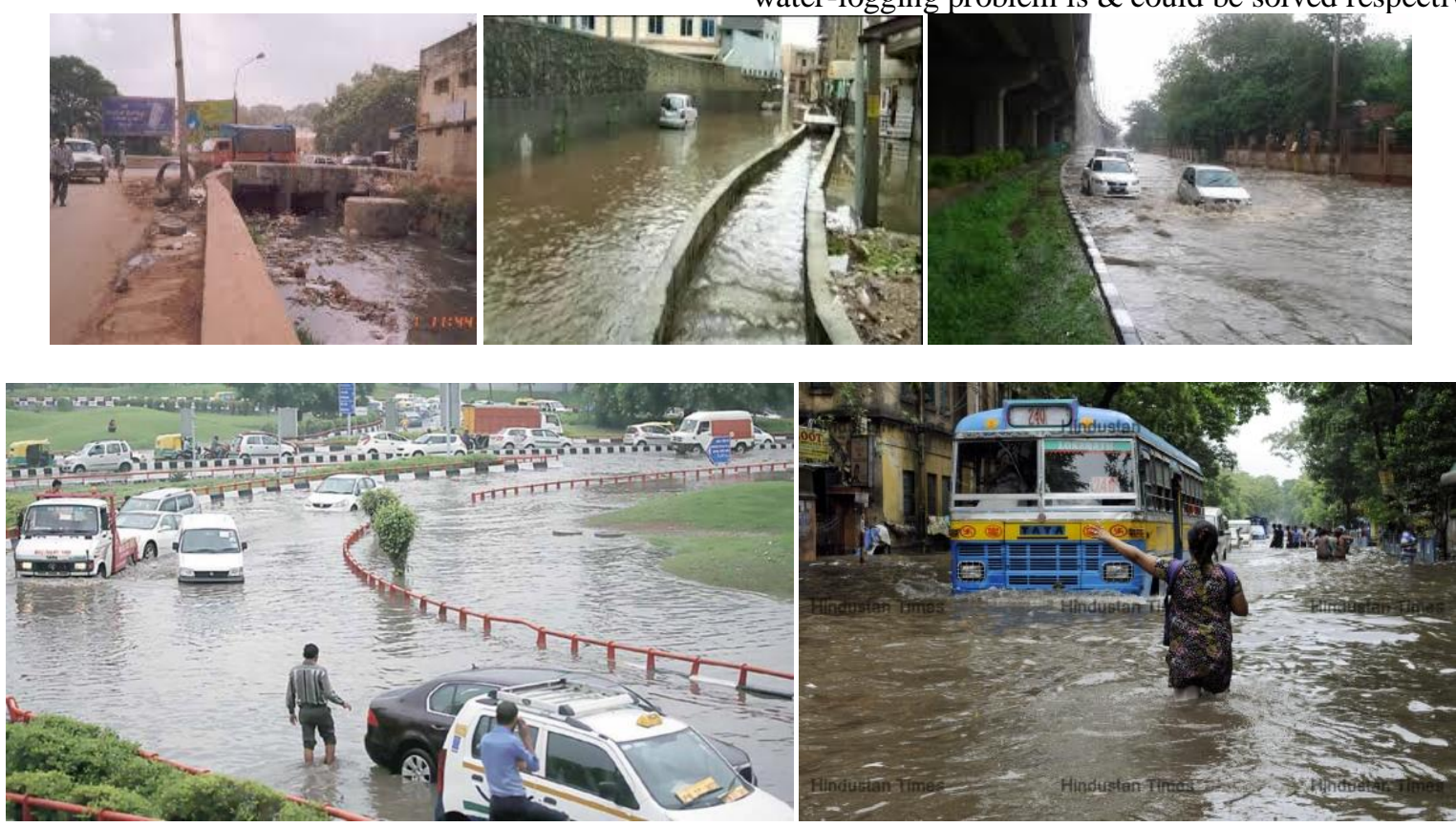

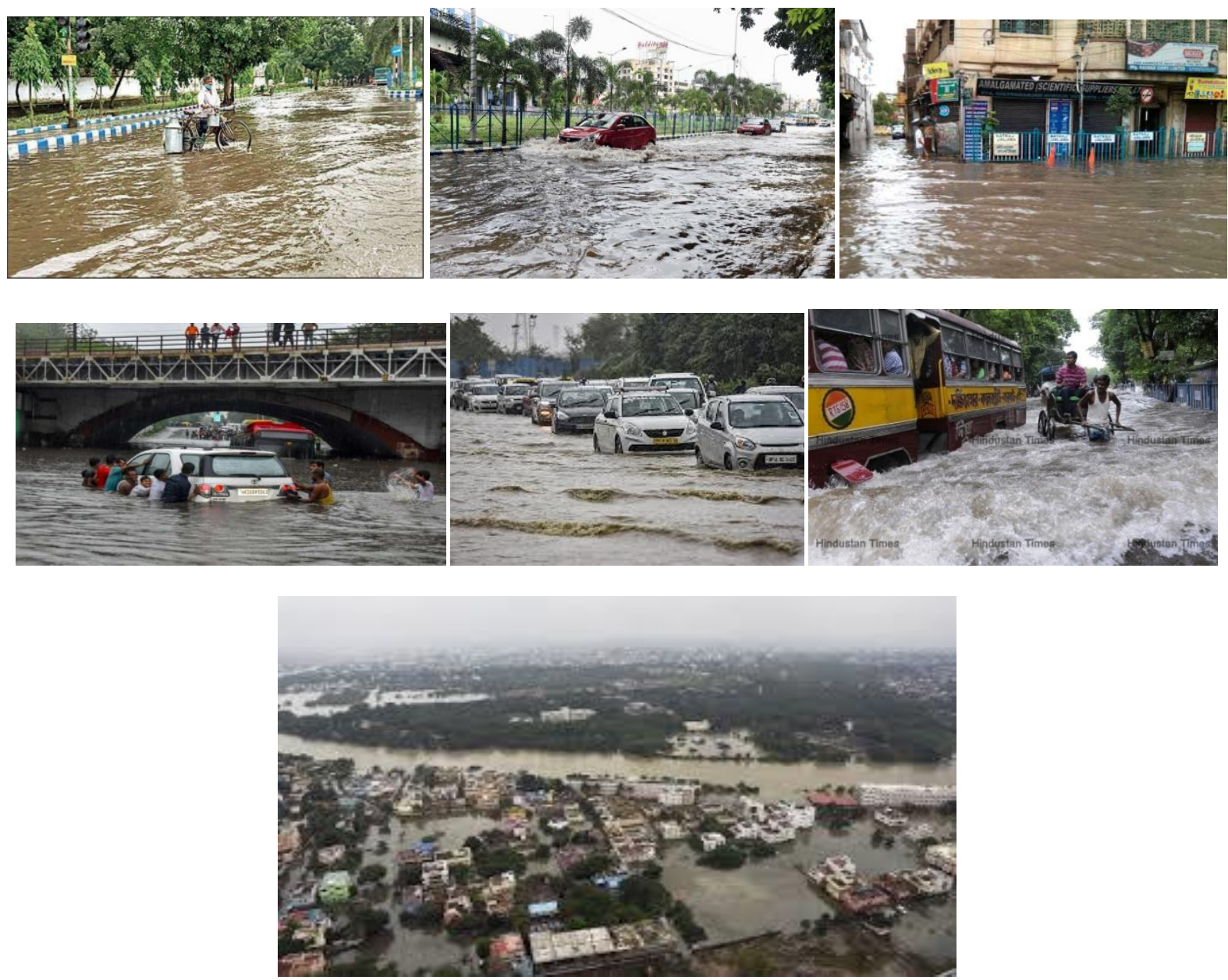

Figure 2: Urban pictures in waterlogging (Source: Web)
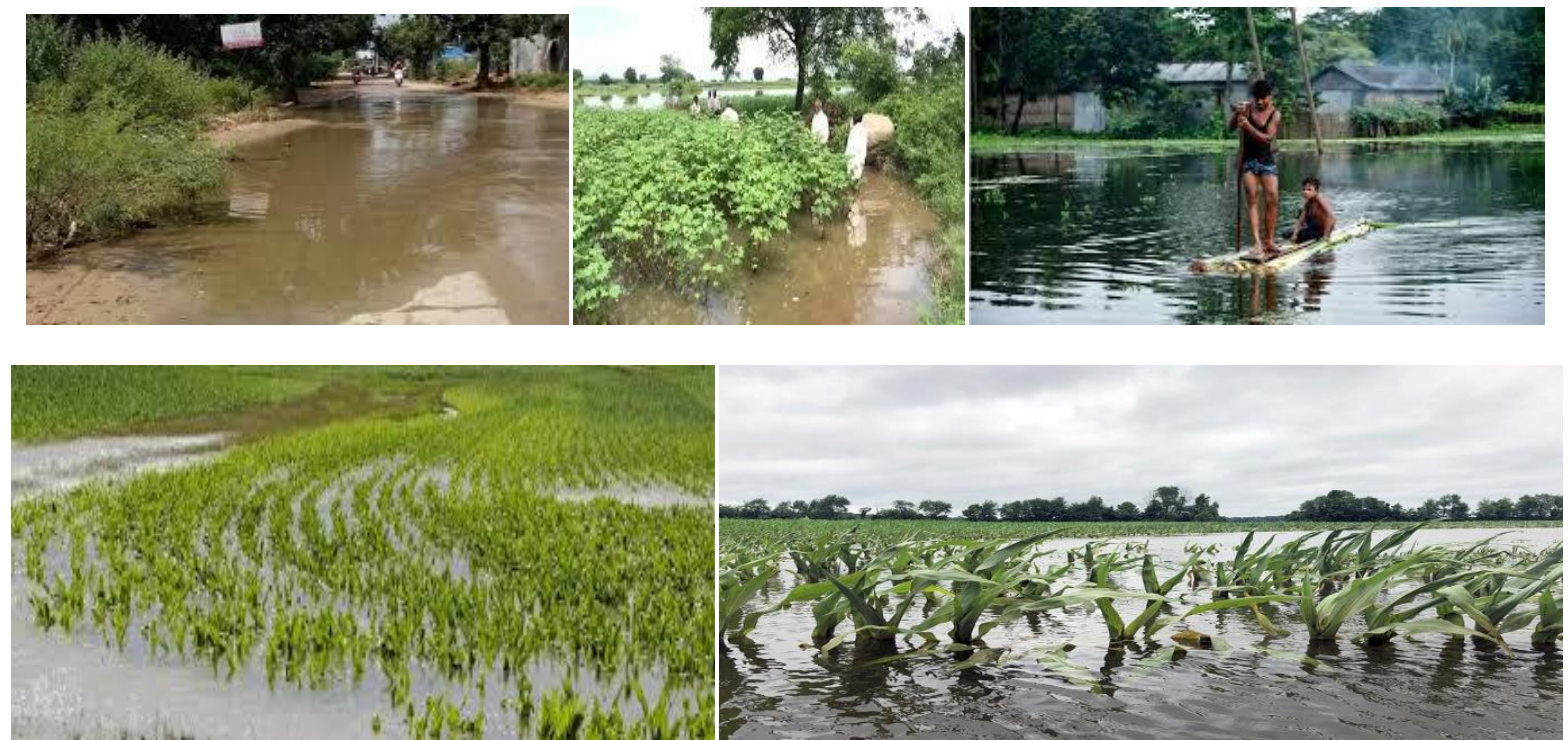

Figure 3: Rustic pictures in waterlogging in village (Source: Web) 

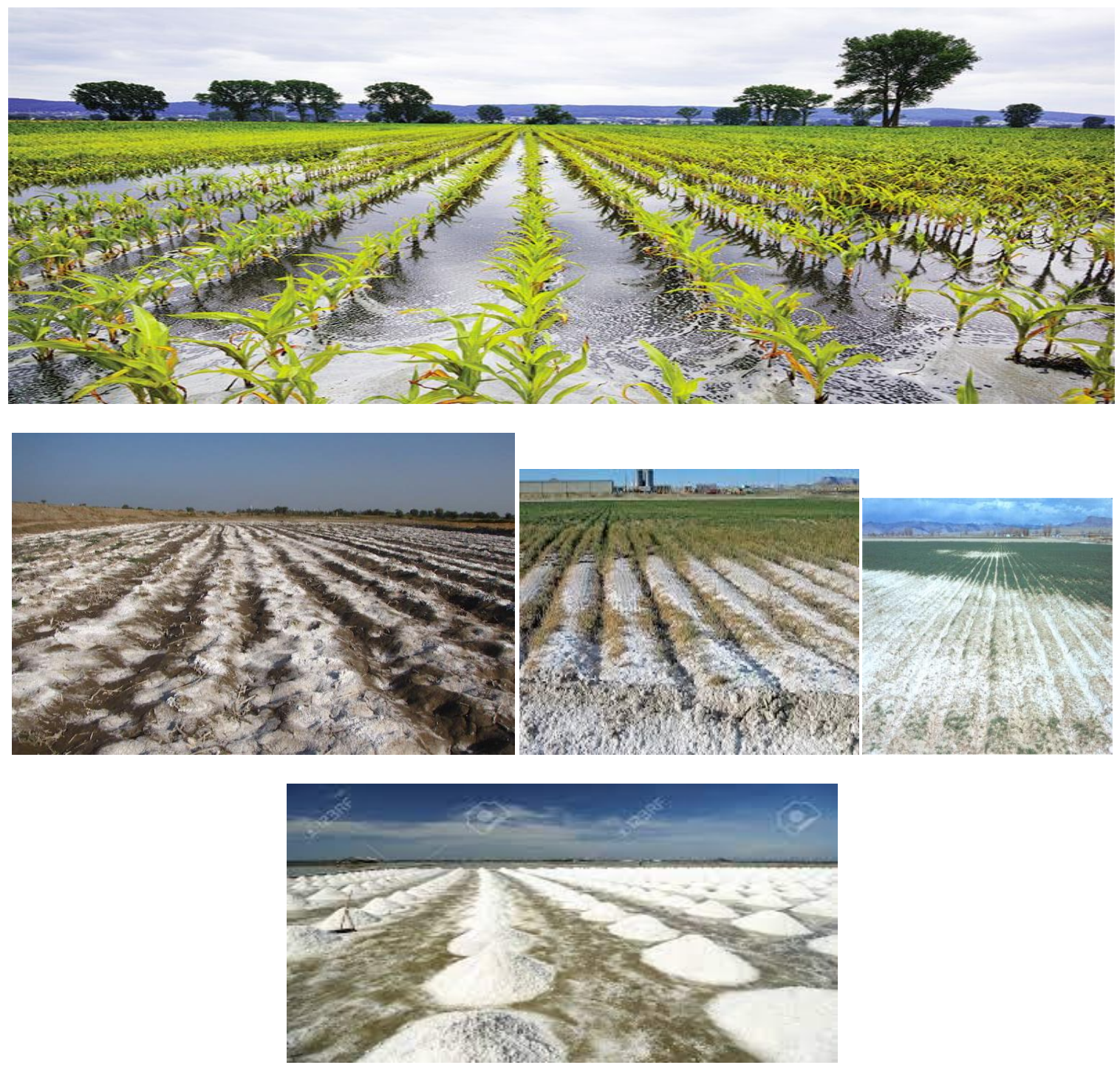

Figure 4: Devastating pictures of salinity effect of waterlogging (also plz. see Ref.5) (Source: Web)

In recent years, most of the cities (metro city) have faced a problem of water-logging despite having a good drainage \& sanitation facility. Several cyclones have destroyed city-life system of drainages. Long-time \& high intensity rainfalls have created out \& made the cities waterlogged to above-the-knee level. In addition to these, several irrigation projects, on the upstream, in every year, do cause the downstream basins flooded ${ }^{(5,}{ }^{6}$. And, the pressure of this water (urban's 'waterlogged' street water) would automatically go to adjoining rural localities \& consequently have made them flooded. It is interestingly increasing to the degree of level of anxiety ${ }^{(7)} \&$ public grievances so increased in recent years. Whatever the cause to be, it can be foresighted that urban localities are usually at higher elevation due to land development so provided in for the city-life infrastructure, than rural places. This study has earmarked by sighting this problem of street water-logging in order to make a solution by its elaborative methodology.

Now, let's describe general feature of waterlogging. As we all know there are generally five types of waterlogging, namely,

- Riverine Flood Waterlogging
- Oceanic Flood Waterlogging

- Seasonal Waterlogging

- Perennial Waterlogging \&

- Sub-soil Waterlogging

There are the following common effects of waterlogging in general:

- On human

- On land (poor soil aeration, $\mathrm{pH}$ alteration, changes in soil nutrients, etc.)

- On field vegetation/crop (retard cultivation, accumulation of harmful salts, growth of waterloving wild plants, etc.)

- On country's economy (loss of cash crops)

- On infrastructure

- On climate

- On social activities

- On general city-life system

- On public perspective about infrastructure system in a locality 
Other effects should include -

- Cultivation in agricultural field gets problematic due to several associates that get their birth by waterlogging

- Construction becomes difficult in the waterlogging area/locality because of higher pore-water pressure affecting soil bearing capacity, leading to higher construction cost

- Groundwater quality goes to inferior level

- Health condition of habitat on upstream leads to poor status

- Soil salinity hampers soil fertility

- Epidemics (breakout of waterborne diseases)

- Unwanted births of cripple plants, bushes, bad roots, etc. on the waterlogged location

- And, lastly, economy of the nation

And, Some common causes of waterlogging:

- Unauthorized habitat on upstream causes stack up of water on downstream

- Unplanned dam/barrage or water training structures

- Impurities in the water fill up the open spaces (pores) of soil-mass, leading to water passage inability

\section{OBJECTIVE OF STUDY}

- To determine water quantity estimation that gets locked in due to waterlogging.

- To solve integrative effect of street \& open land on waterlogging formation.

- To find out innovations to provide reuse vision to the water of waterlogging.

- To design \& plan drainage infrastructure on the view of the water use.

- To create the balanced ecosystem of population distribution on the innovative landscape infrastructure.

- To provide the concept of sustainable land use.

\section{METHODOLOGY}

In month of monsoon season, in India, it is an usual event to occur waterlogging every year, on low-land areas \& on locality where backwaters from uplands get flown over by the huge backpressure of waterflow. These two reasons are mainly happened due to incapable drainage infrastructures, irrigation projects (on upland), road statistics ${ }^{(8,9)}$, rural road renovation condition ${ }^{(10)}$, unstable landscapes, urban road conditions ${ }^{(11)}, \&$ in addition to climate changes. Despite the fact of such changes/challenges ${ }^{(12,}$

${ }^{13)} \&$ rainfall occurrence of every year by magnitude alongwith natural phenomena like cyclone, tornado, hurricane, etc. (simultaneous to monsoon precipitation), which are in total wholly a field \& scope of research interest though, to the concern, there could be several cardinal factors of interest such as town planning system, land topography-terrain status, landscape-drainage system, inlet-cum-outlet discharge points, etc. in gauging \& determining 'safe' \& 'stable' quantity distribution $\&$ reason assessments behind the water stagnancy on street, agricultural field, open land, etc.
During monsoon, waterlogging on streets is a common phenomenon, resulting from rainfall-backed waterflow. It causes disruption to people's lives \& their natural daily activities in many ways, in many forms. It is not rural's concrete-casted roads but also urban's bituminous roads that are found as overflown by such logging in monsoon season. When roads become into such waterlogging, then road-side canal, catchpits, small lakes/ponds, etc. are naturally seen as overflowing (Figure 2). In the monsoon months, every year experiences such incidents causing several difficulties to human life $\&$ infrastructure. Roads are found to be torn up when such water is reduced \& goes away as the season moves to with all-side runoff diminishment. Roads get freed from the waterlogging in less time than their surrounding open lands, canals \& agricultural fields (Figure 3). As long as the waterlogging prevails, disruption increases to manifolds (Figure $4)$.

A good city planning system with high quality drainage management can often suffer over such water containment to about 1 to 2 weeks \& beyond this its capital cost increases, while heavy rainfall stays for 1-2 days ${ }^{(14)}$. Unforesaken to the fact, to be an opportunist to the study as well, that India might only consist $10 \%$ to $20 \%{ }^{(15)}$ to such good quality system of city drainage, besides having $8.3 \%$ (11.6 million hectare) as the sown areas becoming waterlogged in every year monsoon rainfall. It is only data which would be more if agricultural lands (other than sown) are considered alongwith the street area under waterlogging. Fate of this huge amount of water so locked in is the discussion point of this research study that how to make them a point of use by treatment or else.

Table 2: Aspects Of Waterlogging (Major \& its Contributors) ${ }^{\#}$

\begin{tabular}{|l|l|}
\hline Major places of waterlogging & $\begin{array}{l}\text { Contributors to the major } \\
\text { places }\end{array}$ \\
\hline $\begin{array}{l}\text { street, field, open land, valley } \\
\text { area }\end{array}$ & $\begin{array}{l}\text { catch pit, drain, pond, lake, } \\
\text { canal }\end{array}$ \\
\hline
\end{tabular}

${ }^{\#}$ contributors are required to be well designed, forecasted \& efficient to cater the flow.

Street waterlogging if retained on several weeks, drainages get silted \& clogged leading to non-functioning of the operation. Also, the sustained moisture causes to endanger the pavement foundation (premature failure) ${ }^{(16)}$ as moisture has the ability to migrate to the clayey foundation.

During water-logging, break-out of water-borne diseases is a natural phenomenon to happen \& it occurs. Water-logging endangers water supply system into graven problems from drinking/waste water supply (to avid cross-connection) to saline water \& its ability to percolation \& deposition (not permissible if salt content in water more than $3.5 \%)^{(17)}$.

Drains are generally designed to carry annual flood whereas flow quantity due to a heavy rainfall often exceed this limiting ability, resulting to waterlogging formations \& several health risks ${ }^{(18)}$.

Regarding reclamation of soils affected by waterlogging, besides having sub-surface technology ${ }^{(19)}$ of multi-various 'innovative' dimensions ${ }^{(20)}$, envelope materials become a source of cure for 
clayey soils ${ }^{(21)}$. Planar area based tile drainage ${ }^{(22)}$ fundamental should be mentioned in the purpose.

\section{Innovations To Waterlogging:}

Innovation approaches towards waterlogging's solution making has been a long task mankind is delivering over so many years ${ }^{23}$, 24). In modern times, technology has emerged into finding the water-logging problems \& giving various controlling options ${ }^{(25)}$. Several new approaches, like, zonation \&etc, are coming out with the hand of technology's entry blended with remote sensing ${ }^{(26,27)}$. In general, there could be two divisions into the approaches -

- to reduce waterlogging by infrastructural system (drainage system re-design/new/renovation/etc.)

- to reduce or reclaim soils/structures damaged/affected by waterlogging

Our point of discussion is to deal with the first one to cover up the second one (plz. see Table 2).

Innovations are hereby laid down its descriptions on the basis of utilizing the water locked in by waterlogging, on street or open field or elsewhere. It would be worked on three levels in a civil society. The levels are -

- At Individual Level

- At Governmental Level

- By Non-Governmental Organization (NGO)

These three levels could initiate \& build up their respective efforts to make structural arrangement to use the locked in water in monsoon season. When these three levels start using up the water there would be no water seen \& left on the places, major or contributory or else to be causing to the magnitude of hazardmaking or disruptive nature (Table 3). These three levels could produce the following innovations:

\section{INNOVATION OF THE STUDY}

Innovation1. Domestic treatment plant \& storage:

Households shall make by their own budget a small-scale treatment unit to collect, treatment \& store-cum-use the water from their nearby waterlogged areas. The degree of treatment shall decide the cost of treatment \& depends on type of use of such water after the treatment. No water should be used directly or in its raw kind of nature as this may cause several infections like itching, food poisoning, vomiting, burning sensations, etc. so far as the raw nature of such water is concerned. Degree of treatment may become less if such water is withdrawn from the catchment area on the early time of rainfall \& its formation to runoff. Treatment cost may increase if such water already stored or retained on the catchment area for more than 1 week or 10 days (say, variable to locational feature) without further rainfall of significant quantity for a given climate \& atmospheric condition. So, it is less costlier\& beneficial effect to the innovation ( $\&$ its purpose) if clearer portion of such water is collected from the area.

Quantity of collection becomes a major part of this type of innovation. Period of interval to collections is to the needs \&prudent judgement to individual household. Because, there would be limitations to use (at one go \& time) by budget $\&$ space, availability of better water (better monsoon next week!), workability (may be one to its supervising!), climate condition, location specific reasons \& etc.

It is essential to how to treat the water that could be discussed \& solved by any available water treatment consultant at zonal or government level, at its planning level. Here is a scope of employment also.

Portable monsoon storage tank may be made by plastic or PVC as suitable of amenable capacity \& used accordingly to store the treated water during the monsoon season. This type of tank can be easily placed on roof or implemented at any staging height by using necessary appurtenances of PVC made or as suitable, to install \& use as \& when required.

\section{Innovation2. Monsoon treatment plant \& supply:}

This is at government level of service. Concerned government at state-level shall function in this to bring out the innovation.

A demarcated zone is required to be fixed, preferably in a catchment area. In this zone, one small-scale treatment plant should be built up. This plant shall be in use to collect $\&$ treat the water surrounding the plant/zone. This type of plant which is termed here as "monsoon plant" would not necessarily be the treatment plant meant for water supply of a city/town. As the degree $\&$ terms of treatment would be quite isolate $\&$ unique, all provisions regarding its functioning $\&$ all should made up with accordingly. It is obvious to build one monsoon plant in one zone. So, area of zone, its distribution ranges \& other situational attributes should govern the location \& capacity of the monsoon plant. As budget is higher here as compared to earlier innovation that is of domestic concern, this innovation type should be operated \& supervised by government.

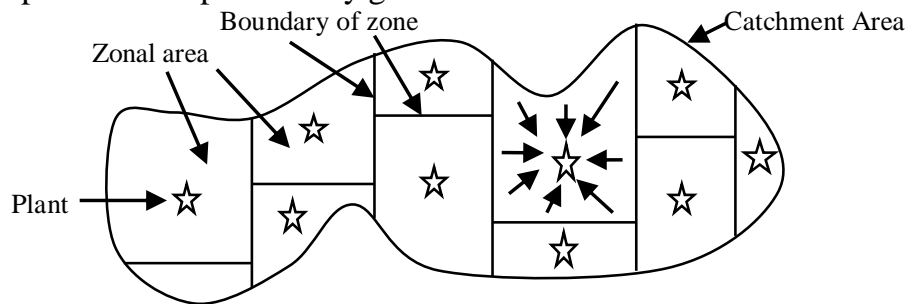

Figure 5: Catchment area with 'innovation' treatment plants Monsoon plant should be such type of plant which should have long term functioning philosophy in its operation, keeping its operational base away from conventional water treatment plant of water supply. At zonal level, it shall be run by local panchayat/municipality, henceforth, it shall be kept as a place of importance to avoid ephemeral chances of destruction. During non-monsoon time, it could operate its functioning, on small 'deputed' zone, by collecting water from nearby canals or such. During dry season for such monsoon plants, maintenance \& expansion activities may be carried out so that it can deliver its operation properly in the monsoon time. A sketch might be thought of to show how such a plant (Figure 5: star marks are the treatment plant) can exist in a catchment area \& serve its functions on to its zonal distribution marks by freeing the lands from water (waterlogging) from its demarcated zone of the area (catchment area). Arrow marks in Figure 5 indicate 'possible' innovation ways by which stacked up water from surrounding 
water-logged areas are to be taking into the plant for the treatment \& use.

This type of plant would be having lots of scopes to broaden its own functioning towards achieving further goals in the service. It would also provide an urban touch to rural places. Peoples would be more \& more appraising with more \& better services, on completely 'free' term. Besides creation of employment, simultaneous operation of service \& earning (may be through taxes, water tariffs, one time charges, etc.) can go side by side in operating such monsoon plant.

This type of plant would not only serve the potable water to its 'deserved' population but they need to be also equipped with to take the local charger to maintain various water-bodies like pond, lake, canal \& even groundwater quality in the zone of the locality. It would have the facility to periodically check, examine $\&$ renovate the existing water quality status to bring up to improved levels - it finally creates a balanced \& healthy ecosystem with overall environment. Such local monitoring vantage of it might also provide groundwater (GW) quality assessment of water use in the existing system (such as underground well, tubewell, etc.) in the locality. So, such system of innovation might act \& start working in collaboration \& cooperation with other authorities (like marine engineering department, coastal authority, irrigation engineering, highway authority, public health engineering, development agencies, etc.) of importance jointly to solve various other related problems of intricacy.

\section{Innovation3. Self-system treatment \& supply:}

It is the innovation completely to be operated \& supervised by non-governmental organization (NGO). The same objective service of removing the water \& giving the water supply to nearby zones of population is here to be given by an independent body of organization apart from any individual household or government as such as described in earlier two innovation types. This type of innovation thereby needs to be looked after \& functioned by NGO.

There would be some places so remote in the concern that individual or government can no longer provide \& sustain the operation \& service thereon. In addition to this particularity, the general zonal concept as narrated in earlier two innovation segments, NGOs may enter in them also \& run the purpose of services as well by their own operational ways \& philosophy.

A large portion of catchment area may be left over by state government to NGOs to provide \& serve the service as well. NGOs would get \& function with more flexibility (than individual government) in operating such service. Depending on variety in zonal situations of waterlogging, NGOs can spread themselves to function in an integrated way \& effective manner to exhibit the innovation as efficient as possible. As it is the unique system completely operated \& monitored by specific NGO, this type of the innovation is hereby called as "selfsystem" innovation. By incorporating NGO's entry into the innovation, way \& level of service is presumed to be more deliberating \& sophisticated - it is very important although while the subject is about remission of land \& public life from waterlogging $\&$ about giving quality water service for the daily uses.

Individual treatment \& storage system, as explained earlier in the first one, may be hired by NGO to run the operation (water treatment \& supply) in a more effective manner to the locale.

\section{Assumptions Of The Innovations:}

- Catchment area is considered as geometrical cylinder with height being the stored water depth.

- The place (city/town/else) is assumed to have proper drainage/infrastructure facility in existing \& operating condition.

- The place (city/town/else) is climate independent to the concern of waterlogging phenomenon.

- The waterlogged place/area is assumed to be likely flown over above H. F. L (high flood level) during monsoon season.

- Waterlogging aspect is irrespective of any geological formation or bed in particular in catchment area.

- Catchment area may be of fertile or futile nature; it's also irrespective to rural or urban discrimination.

- Total time of waterlogging is assumed to be meant to corresponding 'total' stored water quantity (that can be returned back to use by innovation) during a monsoon season.

- Innovation of any kind to the discussed concern should be flexible \& as independent as possible.

- Number of members in a family should be assumed to be five (5) in number as maximum. Innovation should be compatible enough to accommodate any increase in capacity. Lower capacity in the innovation is assumed to be safe.

- Public co-operation is considered to be responsive in good health \& manner to the innovation \& its implementation. To make the innovation practically feasible, required learning knowledge $\&$ its presence is assumed to be constant $\&$ existing in among public from consideration of health \& human hazards \& their respective healthy reclamation/remission.

\section{Advantages Of The Innovation:}

- On Soil Reclamation

- As Alternate Source

- Soil-Water-Climate Integrity

- Effectual Reduction

- Independence over weather

- Cut of spread of water-borne diseases

$>\mathrm{GW}$ contamination

$>$ Mosquito breeding

$>$ Crop culture degradation

Stop of breakout of flies, bad smells, rots, etc.

$>$ Ambience change restriction/control

- Get on improve city \& town planning

- Population relocation

- Low land governance (empty population from low land areas \& relocate them at nearby higher level of ground)

- Local supply system (Monsoon Plant)

- Better Society 


\section{RESULT \& DISCUSSION}

- In keeping on the cardinal objective of making use of water locked on streets, road-side drains, drain's overflows, etc. as often seen in post-monsoon period, entire discussion of the innovations should be on overall basis to the zonal level necessaries.

- There are three innovations discussed \& also a rational view of consuming such water is in given in the tabulation to showcase the internal purposes that can be fulfilled by the innovations suitably.

- It is well perceived by the discussions that the water could serve as the valuable means on 'frightened' times (of time of heavy rainfall, etc.) to give mankind a new scope of their 'useful' water management $\&$ a relief from waterlogging.

- Various modifications could be determined \& established in pursuance of waterlogging minimization $\&$ simultaneously usefulness of the water in several possible ways, like the innovations of the study, by giving a reigning thought on the huge running flows.

\section{CONCLUSION}

- Urbanization rate of growth is almost eye-catching in every state \&country ${ }^{(28)}$. It is a good sign of infrastructural upliftment\& country's economy status. This entire system of infrastructure should achieve the advancing marks once it could deliver the city servicing with such innovations or else that could provide a

Table 3: Treatment Options^

\begin{tabular}{|c|c|c|c|c|}
\hline \multirow{3}{*}{$\begin{array}{l}\text { Quality } \\
\text { Type of } \\
\text { Water }\end{array}$} & \multicolumn{4}{|c|}{ Treatments prescribed (by necessary limit) against innovations of } \\
\hline & \multicolumn{2}{|c|}{$\begin{array}{l}\text { Domestic treatment plant \& } \\
\text { storage-cum-use }\end{array}$} & \multirow{2}{*}{$\begin{array}{l}\begin{array}{l}\text { Monsoon } \\
\text { treatment } \\
\text { plant } \\
\text { supply }\end{array} \\
\text { Potable only }\end{array}$} & \multirow{2}{*}{$\begin{array}{l}\begin{array}{l}\text { Self-system } \\
\text { treatment } \\
\text { supply^ }\end{array} \\
\begin{array}{l}\text { (Potable } \\
\text { potable), non- } \\
\text { suitable }\end{array}\end{array}$} \\
\hline & $\begin{array}{l}\text { Without } \\
\text { potable }\end{array}$ & Potable & & \\
\hline High TS & $\begin{array}{l}\text { Alum } \\
\text { dose @ 17 } \\
\mathrm{mg} / 1\end{array}$ & $\begin{array}{l}\text { Alumdose@17 } \\
\text { mg/l }\end{array}$ & \multirow{4}{*}{$\begin{array}{l}\text { Conventional } \\
\text { treatment } \\
\text { units on } \\
\text { "small-scale } \\
\text { basis" }\end{array}$} & $\begin{array}{l}\text { + extra provision } \\
\text { such as setting } \\
\text { tank \& etc. }\end{array}$ \\
\hline $\begin{array}{l}\text { High } \\
\text { Hardness }\end{array}$ & $\begin{array}{l}\text { Lime- } \\
\text { Soda/Zeolit } \\
\text { e } \\
\text { application }\end{array}$ & $\begin{array}{l}\text { Lime- } \\
\text { Soda/Zeolite } \\
\text { application }\end{array}$ & & $\begin{array}{l}\text { + extra provision } \\
\text { such as } \\
\text { ionization } \\
\text { process \& etc. }\end{array}$ \\
\hline Filtration & $\begin{array}{l}\text { Not } \\
\text { required }\end{array}$ & $\begin{array}{l}\text { Rapid sand } \\
\text { filtration }\end{array}$ & & $\begin{array}{l}\text { + extra provision } \\
\text { such as bio- } \\
\text { filtration, tube } \\
\text { settlers, aerobic } \\
\text { treatments, etc. }\end{array}$ \\
\hline $\begin{array}{l}\text { Disinfect } \\
\text { ion }\end{array}$ & $\begin{array}{l}\text { Chloride } \\
\text { tablets } \\
\text { (suitably @ } \\
\text { mg/l) or } \\
\text { bleaching } \\
\text { powder in } \\
\text { mg/l unit }\end{array}$ & $\begin{array}{l}\text { Chloride tablets } \\
\text { (suitably @ } \\
\mathrm{mg} / \mathrm{l} \text { ) or } \\
\text { bleaching } \\
\text { powder in } \mathrm{mg} / \mathrm{l} \\
\text { unit (to } 0.02 \\
\mathrm{mg} / \mathrm{l} \text { as residual } \\
\text { chlorine limit) }\end{array}$ & & $\begin{array}{l}\text { + extra provision } \\
\text { such as } \\
\text { fluoridization, } \\
\text { Iron \& } \\
\text { manganese } \\
\text { plant, arsenic } \\
\text { plant, etc. }\end{array}$ \\
\hline
\end{tabular}

$\wedge$ high Alkalinity, salinity or others could also be prescribed in accordance to BIS (BIS: Bureau of Indian standards).

${ }^{\wedge}$ it is in combination of domestic \& monsoon treatment provisions in addition.

- Once urban areas are serviced by such innovations they would not only be free of waterlogging but that relaxes broader life to urban drainages alongwith patch-free, hassle-free, more engineering bound infrastructural service system.

- The study's innovations could offer a degree of freedom $\&$ independency to individual household/apartment.

- Even 'existing' drains of lower servicing category would not be though perceptible enough to be accountable in the output if housing infrastructures are equipped with the prescribed innovations altogether on all along. Suitable accommodations of use could be mentioned for them without demolishing them.

- Only 2\% of agricultural land (in hectare) in India affected by waterlogging while $10 \%$ affected by salinization $^{(29)}$ each year approximately though it's increasing also. This feature could be decreased, (especially to the $10 \%$ magnitude) by providing the innovations as applicable.

- Common ways to control the waterlogging should never be forgotten $\&$ in addition to the suitable innovation of the study it includes ${ }^{(30)}$ control seepage loss/inflows \& outflows, free of rainwater, stop to use of fertilizer chemicals (alkaline, etc.), landscape to level up, drainage system, mulching, etc.

- An exemplary tabulation of possible treatment units that can be applied \& provided against the innovations is shown in Table 3 where only some specific qualities are included to get the water treated down to the respective quality standard, as for the innovation indeed.

its influences on rural areas. Rural places adjoining to urbans would not be getting the urban flows on monsoon season, resulting to backwater pressure minimization as caused by urban. This leads to restriction to flows \& consequent minimization in waterlogging on the downstream catchment areas.

- Prevention \& avoidance to water use to unused 'waste' water like the waterlogging flows should be stopped everywhere (by turning into making such innovative measures to implementation) to make the future of infrastructure a higher one to the prosperity grade.

- There are very natural causes of waterlogging such as ${ }^{(30)}$ geology, soil type, physiography, weather (heavy rainfall, cyclone, flood, etc.), seepage inflows \& lastly excessive irrigation $\&$ poor drainage facility. The given innovations could work with efficiency to all possible causes to decrease the effect \& the event to lower degrees.

- While landforms in flood basins and coastal plains acting as 'kidneys" as 'good' ecosystem of earth ${ }^{(31)}$, the innovations so described would augment the ecological functions to even more higher magnitude to create better society, drainage, wetland, irrigation, ecology \& agricultural system.

\section{RECOMMENDATION}

- Contour mapping: It would be a better controlling mechanism if zone-wise contour of several atmospheric variables (like temperature, solar radiation, rainfall, 
relative humidity, etc.) are available or made plotted by historical/experimental data. It would facilitate to plot the correct location in placing the innovation.

- Cylindrical catchment area may be changed to suitable description.

- Urban agglomerations should be with respect to providing the innovations to make $\&$ create a total balance in the ecosystem \& city-life habitat.

- Spatial technique ${ }^{(32)} \&$ sub-surface drainage technology $^{(33)}$ with required fundamentals to emphasis more \& more.

- Salinity management: it is a gravely problem. Several adoptions (such as innovations or else like chemicals to use $\&$ etc.) could be blended into the innovations.

- Groundwater management: Entire innovation should not forget or merely neglect even mild contamination (to avoid accumulative effect) to groundwater table ${ }^{(34)}$. Several required policies could be taken up at administrative level or else to get up the level to the par. Altogether planning ${ }^{(35)}$ is essential to provide less partial management \& create a 'perennial' solution field to the concern.

- $\quad$ Illiteracy \& Political Issue: It with its severity makes drainage areas encroached/narrowed down to a locality's facility. So, it should be handled with care \& after all improved with liberal mindsets.

- Water Resources Planning: Wetlands should be preserved. Various projects could be created like excavation \& catering of new ponds (small, medium, large) in a locality of water-logging where they would work as reservoir to act as sustenance.

- Rainwater Harvesting: It should be regulated as a mandatory for all houses (new \& old).

- Irrigation structures \& infrastructures: All old irrigation \& barrage structure should be renovated to take care of design floods based on its present structural capacity. New structures (especially on downstream) should be banned without careful future anticipation \& present waterlogging scenario in its locality. Use of plastics should be handled with care.

- Habitat Landscape: It should be given high valuation with regards of their distributive presence over surrounding open land \& topography.

- Drainage slope \& usage of pumps should be annually maintained with capacity functioning.

- Irrigation control structure should be increased by number.

- Tree plantation \& drainage system to be good enough to minimize waterlogging effects.

- Raised Groundlevel to be maintained on all along the location surrounding waterlogging phenomenon.

- Planning of rural areas to avoid alkaline water to get mixed with the waterlogging water.

- Seepage loss from canal to be reduced by lining, etc.

- Various practices like mulching to be taken with great care, precaution \& preservation to control groundwater quality, civilization health \& future cultivations.
- Uninterrupted field recycling: open lands that remain in less affection of waterlogging should be made into planning to relax the affected lands in a locality.

- Singular drainage system: to avoid unnecessary blockade of water mass \& to maintain uniform distribution, system of single drainage is hereby prescribed alongwith the innovations.

\section{REFERENCES}

[1] Deborah Balk, Mark R. Montgomery, Hasim Engin, Natalie Lin, Elizabeth Major and Bryan Jones, 2019, Urbanization in India: Population and Urban Classification Grids for 2011,Data 2019 (www.mdpi.com/journal/data), 4, 35, doi:10.3390/data4010035, pp. 1-16

[2] https://www.indiatoday.in/cities/mumbai/story/mumbai-rain-waterloggingimd-train-status-traffic-live-updates-news-1830650-2021-07-21

[3] Economic Survey Of Delhi, 2018-19, pp. 23-41.

[4] Census Of India 2011, 2019, Population Projections For India And States 2011 - 2036 - Report Of The Technical Group On Population Projections, National Commission On Population (Ministry Of Health \& Family Welfare) Nirman Bhawan New Delhi - 110011, pp. 1-264.

[5] Also, http://www.censusindia.gov.in/DigitalLibrary/MFTableSeries.aspx

[6] B Bowonder, K V Ramana and R Rajagopal, 1986, Waterlogging in irrigation projects, Sadhana, Vol. 9, Part 3, November 1986, pp. 177-190.

[7] Ria Roy, Md Kutubuddin Dhali, 2016, Seasonal Water logging Problem In A Mega City: A Study of Kolkata, India, Quest Journals(www.questjournals.org), Journal of Research in Humanities and Social Science, ISSN(Online) : 2321-9467,Volume 4, Issue 4 (2016), pp: 01-09.

[8] R Raju, K Thimmappa, Parveen Kumar, Satyendra Kumar and RS Tripathi, 2016, Impact Analysis of Reclamation of Waterlogged Saline Soils through Subsurface Drainage Technology in Haryana, Journal of Soil Salinity and Water Quality, 8(1), pp. 72-81.

[9] Ministry of Road Transport and Highways (MoRTH), Government of India Transport Research Wing, 2018, BASIC ROAD STATISTICS, www.morth.nic.in, New Delhi.

[10] Ministry of Road Transport and Highways (MoRTH), Government of India, Transport Research Wing, 2016, BASIC ROAD STATISTICS OF INDIA, www.morth.nic.in, New Delhi.

[11] Planning Commission (Ministry of Rural Development Government of India), 2011, Final Report - WORKING GROUP ON RURAL ROADS IN THE 12th FIVE YEAR PLAN, pp. 1-110.

[12] Public Works Department (Government of Delhi), December 2014, Urban Roads Manual (Second Edition), pp. 1-217.

[13] Sanjay Kumar Singh, 2012, Urban Transport in India: Issues, Challenges, and the Way Forward, European Transport|Trasporti Europei, ISSN 18253997, (2012), Issue 52, Paper ${ }^{\circ}$ 5, pp. 1-26.

[14] Sudarsanam Padam \& Sanjay K. Singh, Urbanization And Urban Transport In India: The Sketch For A Policy, pp. 1-27.

[15] P. Singh, Drainage problems in India, Country Papers Ill, pp. 278-285.

[16] Bureau Of Indian Standards, 1993, Handbook On Water Supply And Drainage (With Special Emphasis On Plumbing), SP 35 : 1987, New Delhi 110002, pp.1-173.

[17] Indian Roads Congress, 2014, Guidelines Of Road Drainage (First Revision), IRC:SP:42-2014, pp. 1-138.

[18] Bureau Of Indian Standards, 1993, Handbook On Water Supply And Drainage (With Special Emphasis On Plumbing), SP 35 : 1987, New Delhi 110002, pp.1-173.

[19] https://www.who.int/water_sanitation_health/hygiene/settings/hvchap5.pdf? ua $=1$

[20] Bundela et al., 2016, Cost Estimation of Sub-Surface Drainage Systems for Reclamation of Waterlogged Saline Lands, Journal of Soil Salinity and Water Quality 8(2), pp. 131-143.

[21] Prasanta Biswas, 2018, A Propositional Brief About Making Simultaneous Irrigation \& Drainage Applying Underground Construction in Cultivation Field, International Journal of Technology and Science (IJTS) - i3c publication, ISSN (Print) 2350-1103, ISSN (On-line) 2350-1111, Vol. 5 , Issue 2, pp: 9-17. URL: http://www.i3cpublications.org/ 
[22] H.P. Ritzema, T.V. Satyanarayana, S. Raman \& J. Boonstra, 2008, Subsurface drainage to combat waterlogging and salinity in irrigated lands in India: Lessons learned in farmers' fields, Agricultural Water Management, 95 (2008), pp. 179-189.

[23] Prasanta Biswas, "Determining Planar Tile-drain Spacing (Axial) in Areas subjected to Water-logging", International Journal of Civil Engineering Research (IJCER) - FOREX publication, ISSN: 2347-470X, Vol. 6, Issue 2, Edition: April 2018, Page: 30-43. URL: www.forexjournal.co.in

[24] Prof. P.N. Mehrotra \& Shri Ramji Pandey, 2009, Management of Waterlogged Areas in Uttar Pradesh, Study no. 128, Publication No. 175, Agro-Economic Research Centre (University of Allahabad, Allahabad211002, India), pp. 1-138.

[25] Sahoo et. al., 2006, Integrated Management Approaches for Waterlogged Ecosystem (Research Bulletin Publication No. 30), Water Technology Centre For Eastern Region (ICAR India),Chandrasekharpur Bhubaneswar Orissa 751023 India, pp. 1-30.

[26] Shishir Raut, G. Kar And N. Sahoo, 2016, Study of waterlogging and drainage in relation to soil in coastal Odisha using remote sensing and GIS, J. Indian Soc. Coastal agric. Res.,34(1), pp. 156-157.

[27] National Institute Of Technology (Jalvigyan Bhawan), 2001, Remote Sensing And GIS Applications In Zonation Of Waterlogging In Irrigation Command, CS/AR-18/2000-2001, Roorkee 247667, Uttaranchal, pp.1-44.

[28] S.K. GUPTA, 2002, A century of subsurface drainage research in India Irrigation and Drainage Systems, 16: 69-84, 2002, Kluwer Academic Publishers, pp. 69-84.

[29] Dr C. Chandramouli, 2011, Rural Urban Distribution Of Population Census Of India 2011 (Provisional Population Totals), Registrar General \& Census Commissioner, Ministry Of Home Affairs, New Delhi India, pp.1 39

[30] https://www.fao.org/3/v4360e/v4360e06.htm

[31] https://www.conserve-energy-future.com/types-causes-effects-solutionswaterlogging.php

[32] http://www.iitk.ac.in/waterwoes/waterlogging.html

[33] S. Roy Chowdhury, A.K. Nayak, P.S. Brahmanand, R.K. Mohanty, S. Chakraborty, A. Kumar and S.K. Ambast 2018 Delineation of Waterlogged Areas using Spatial Techniques for Suitable Crop Management in Eastern India Research Bulletin No. 79 ICAR-Indian Institute of Water Management Bhubaneswar-751023, Odisha, pp.1-52.

[34] Sharma et. al., Reclamation of Waterlogged Saline Soils through Subsurface Drainage Technology ICAR-CSSRI/Karnal/ Technology Folder/ 2016/02 ICAR-Central Soil Salinity Research Institute Karnal-132 001 (Haryana), pp. 1-4.
[35] B.M.Jha \& S.K.Sinha, Towards Better Management of Ground Water Resources in India Central Ground Water Board Bhujal Bhawan, CGO Complex, NH IV, Faridabad- 121 001, Haryana, India.

[36] Planning Commission Government Of India, 2013, Report Of The High Level Expert Group On Water Logging In Punjab, pp. 1-95.

\section{AUTHORS}

First Author - Prasanta Biswas, Assistant Professor,

Department Of Civil Engineering, Global Institute Of

Management And Technology (G.I.M.T) West Bengal, India,

Whatsapp: +91-9874096289, E-Mail:

b.prasantagimt@gmail.com

Second Author - Sourojit Das, Assistant Professor, Department

Of Civil Engineering, Global Institute Of Management And

Technology (G.I.M.T) West Bengal, India, Whatsapp: +91-

8116020196, E-Mail: sourojit.das@ gmail.com

Third Author - Arindam Prasad Sinha, H.O.D \& Assistant Professor, Department Of Civil Engineering, Global Institute Of

Management And Technology (G.I.M.T) West Bengal, India,

Whatsapp: +91-9732129532, E-Mail: arindampp@gmail.com

FourthAuthor - BiltuMondal, Student, B.Tech 4th Year 7th

Sem (MAKAUT University Roll No: 25901318133), Department

Of Civil Engineering, Global Institute Of Management And

Technology (G.I.M.T) West Bengal, India, Whatsapp: +91-

9800955197, Email: biltumonda1955@ gmail.com

Fifth Author - Jayanta Kumar Karmakar, Student, B.Tech 4th

Year 7th Sem (MAKAUT University Roll No: 25901318132),

Department Of Civil Engineering, Global Institute Of

Management And Technology (G.I.M.T) West Bengal, India,

Whatsapp: +91-9635514390, Email: karmakarj712@gmail.com

Sixth Author -Nabamita Sen, Student, B.Tech 4th Year 7th

Sem (MAKAUT University Roll No: 25901319088), Department

Of Civil Engineering, Global Institute Of Management And

Technology (G.I.M.T) West Bengal, India, Whatsapp: +91-

8918873714, Email: donasen97@ gmail.com 